УДК 32.001

\title{
ПОЛИТИЗАЦИЯ ПРИВАТНОЙ СФЕРЫ И ДЕМОКРАТИЧЕСКИЕ РЕСУРСЫ В ДИНАМИКЕ ОТНОШЕНИЯ К ЖЕНЩИНЕ В ПОЛИТИКЕ
}

\author{
(C) 2012 г. О. А. Дуброва
}

\section{Новочеркасская государственная мелиоративная академия}

В представленной статье раскрывается соотношение публичного и приватного в политике и формируется концепция приватного, как альтернативы традиционной политики. Приватная сфера мыслится автором, как мощңный демократический ресурс, как способ возвращения женщины в политику на основе политического партнёрства. Написанная языком теории политического представительства статья содержит кониептуальные положения позволяющие предвидеть тенденщии нарастания женской субполитики.

Ключевые слова: «женский вопрос»; права женщин; политическая активность женщчин; политическое представительство женщчи; политизация; приватная сфера; публичная сфера; политическое и неполитическое; женская субполитика.

The article reveals correlation between the public and private in politics and gives the notion of the private as an alternative to traditional politics. Author describes the private sphere as a powerful democratic resource, a way of returning of a woman into politics on the basis of political partnership. Written in terms of political representation, the article gives conceptual propositions, making it possible to foresee the tendencies of woman sub-politics intensification.

Key words: women's question; women's rights; women's political activity; women's political representation; politicization; private sphere; public sphere; the political and non-political; woman sub-politics.

Очевидно, что в современной политической жизни «женский» вопрос может рассматриваться в трех значениях. Во-первых, в центре общественного внимания оказываются права женщины как следствие политики прав человека, в которой, собственно, проблемы женщины «тонут» в дискуссии о превосходстве системы демократических ценностей над различными «нативными» концепциями (религиозными, культурно-традиционалистскими).

Во-вторых, существует проблема политической активности женщин, их роли в политических процессах во влиянии на общественно-политические перемены, что связано со стремительным изменением геополитической и политической картины современного мира и является вопросом, содержащим различные, часто резко расходящиеся, оценки.

В-третьих, в эпоху массовых общест- венных движений, выходящих в наднациональный глобальный уровень, популярными становятся рассуждения о женском представительстве в политике, как инструменте демократизации общественной жизни и общественных настроений.

Учитывая эти обстоятельства, в предлагаемой статье содержится попытка осуществить анализ этих вопросов несколько с неожиданной стороны, с исследования сферы приватной жизни, которая, казалось бы, утвердилась как сфера неполитического, но является сильным аргументом в дискуссии о том, каким образом возможна самореализация женщины как личности, как ее социальные роли согласуются с политической активностью, к каким последствиям может привести политизация приватной сферы.

Заявленная исследовательская схема будет неполной, если не определить влияние 
демократических ресурсов, институтов и процедур, которые направлены на обеспечение принципов равенства и свободы в политическом процессе, и обеспечивают гарантии для участия женщин в политической жизни.

Сложность представляет определение сферы приватной жизни, которая традиционно ассоциируется с семьей, личными интересами, свободным временем, досугом, социально-бытовыми практиками. В политической мысли особый смысл придается семье как социальному институту, с которым идентифицируются жизненные траектории женщин. Интересно, как пишет С. Окин, «большинство феминисток XIX и XX вв. не ставят под сомнение и не отрицают особой роли женщины в семье. Они часто требовали для женщин равных прав и возможностей, например, образования или избирательного права, на том основании, что это их сделает либо лучшими женами и матерями, либо позволит им связать особые моральные качества, развившиеся в домашней сфере, с миром политики» [1].

Выдержанная в согласии с ценностями модерна позиция состояла в том, что женщина способна «облагородить» политическую жизнь, внести дух разумности, морализма, согласия, ограничить агрессивность и конфликтность участников политической жизни. Иными словами, возникал компромисс между традиционализмом, отводящим место женщине преимущественно в домашней жизни, и идеями прав и прогресса, нацеленным на равенство в доступе к политическим ресурсам и политической карьере.

Радикализм феминисток, заявляющих о безусловном «уничтожении» семьи, на мой взгляд, явился следствием разочарования в осуществлении умеренной позиции, находя объяснение в воспроизводстве зависимости женщины от мужчины при сохранении статуса домохозяйки, и предопределяемой несамостоятельностью политической жизни в качестве рядового избирателя. Для них выход женщин в политику означал разрыв с семейной традицией и дистанцирование от политики компромиссов с традиционалистами.

Современная политическая мысль сталкивается с проблемой кризиса семьи в контексте распада традиционных семейных ролей и связей, утраты привычных функций и феми- низации экономической и социальной жизни. Аргументы, которые казались безупречными в период доминирующего влияния приватной (семейной) сферы, не оцениваются таковыми при альтернативной, набирающей силу, деловой или общественной карьеры женщины. Радикализм констатирует несоответствие между ростом влияния женщины, как экономически и социально самостоятельной личности, и ее подчиненным статусом в политической жизни.

Предлагая концепцию реванша, основанного на устранении барьеров в политической практике и политическом сознании, радикальный феминизм ставит целью не просто закрепление за женщиной права занимать высокие должности, но и быть независимой в политических решениях от мужчин личностью, подходить к оценке политической ситуации в контексте женского вопроса, соответствия критериям равенства и свобод женщин в обществе. Скандинавские страны (Норвегия, Финляндия, Дания, Исландия) внешне демонстрируют успешность феминистских действий, воплощение в реальность мечты о матриархате в политике, но за политической сценой существуют немаловажные проблемы, требующие теоретического осмысления.

Достижение равенства женщины и в политической, и в приватной сферах не может быть абсолютным. Оно, скорее, представляет баланс позиций, связанных с тем, какие схемы политического участия и представительства женщины доминируют в общественном сознании, какие ожидания основываются на «пришествии» женщин в политику, как совмещается деятельность женщины в приватной сфере и ее политическая судьба.

Кроме того, можно считать, что не закончен спор между сторонниками отмены различий между общественным и частным и теми, кто полагает, что женщина имеет право на уединение, на личное в человеческой жизни. Постмодернизм, восприняв идею М. Фуко о паноптическом государстве, где семейный дискурс навязывается и репрессивен по отношению к женщине, заявляет, что женский вопрос в политике абсурден, выражая интересы власти, смещающей оценку положения женщины в ее политический статус и интегрируя в систему ограничения и подчинения.

Собственно, движение за права женщин 
в политике эволюционировало от социалистической мечты о полном равноправии женщины и мужчины, как граждан, к «дивидности», заострении проблем однополых браков, защиты от сексуальных домогательств, что свидетельствует о разочаровании в идеалах модерна и переходе к модели нового индивидуализма, провозглашающего дистанцию от системной политической жизни, в контексте зарождения субполитик, удовлетворяющих специфически женские интересы, которые не могут быть адекватно проинтерпретированы и оценены на уровне традиционных демократических институтов. И в этом смысле, возникает вопрос о том, какой является по содержанию тенденция женского вопроса, расширением демократических прав женщин или дедемократизацией, возвращением в измененном варианте к неравенству женщин и мужчин в политической жизни.

Очевидно, что не существует особой женской политики, также очевидно, что в политической жизни не может быть конфронтации по так называемым «естественным» половым различиям. Устанавливая эти положения, необходимо выявить способы, средства, пути, по которым движется современное женское движение, опираясь на накопленный коллективный опыт и институциональные (демократические) ресурсы, при этом, сохраняя легитимность политических притязаний и потенциальную поддержку в обществе.

Обращая внимание на консенсус относительно прав женщины, следует подчеркнуть, что участие женщин в политике радикально не изменяет характер общественно-политического устройства (в теократическом Иране женщины заседают в парламенте и являются министрами, не образуя группу политического обновления, ориентированную на секуляризацию общественно-политической жизни).

Сторонники политики прав женщины постоянно указывают на несоответствие положения женщин в «недемократических» сообществах современным политическим стандартам: не вступая в дискуссию по поводу универсальных прав человека и традиционного права, можно сказать, что оценка положения женщины в политике определяется, все-таки, неформальными количественными показателями и даже не фактом присутствия женщины в верховной власти (президент, премьер-министр, председатель парламента). Проблема состоит в том, что происходит процесс сужения сферы «большой» политики. Классические партии, институты управления и представительства интересов постепенно перестают удовлетворять многообразию запросов современного общества.

Это замечание в полной мере относится и к женской проблематике в политике. За истекший 200-летний период, с возникновением феминизма, женщины добились, казалось бы, зримых успехов в обретении избирательного права, создании женских ассоциаций, клубов, присутствии в органах исполнительной и законодательной властей, но доминанта политической жизни существенно не изменилась: представительство женщин в политике стало способом достижения целей женской «элиты», интегрироваться в правящий класс и формой делегирования интересов от имени женщин структурами, нацеленными на реализацию политических амбиций, часто не совпадающих с реальными проблемами женщин в обществе.

Кроме того, усилилась латентная дискриминация женщины, связанная с тем, что, в результате политизации приватной сферы, точнее, ограничения возможностей женщин проявлять свои моральные и социальные качества вне политики, женщины «потеряли» авторитет как носители традиционных добродетелей, но не обрели политической мобильности, не стали «тяжеловесами» в политической жизни.

Также, воспроизводится конфликт между интересами женщин в политике и приватной сфере, выражающийся в навязывании женщинам образцов политически конформного поведения, следования кодам лояльности легальным нормам и правилам, что реально ограничивает возможности женщины во влиянии на приватную сферу.

Политизация приватной сферы, перевод в публичный дискурс вопросов, касающихся семейных ролей и отношений, интересов женщины, имеет двоякое значение. С одной стороны, формально расширяется сфера индивидуальной свободы, укрепление социально-имущественного и семейного статуса женщины. С другой - женщины становятся беззащитными перед вторжением в частную жизнь, будь то со стороны государственных 
институтов, СМИ или общественных организаций. Женщине отказывают вправе быть самостоятельной и компетентной в сфере, которая всегда традиционно ассоциировалась с образом женщины, на которую реально мужчины не посягали.

Становясь частью политического, приватная сфера создает массу возможностей миниатюризации политики, увода от кардинальных политических проблем, делает частную жизнь критерием оценки политической деятельности, «вымывает» из политики ее идейно-мировоззренческий и стратегически-планирующий смыслы. Поясняя это положение, можно показать падение качества политической жизни в Европе, где наступила эпоха политических скандалов, связанных с личной жизнью персонажей (С. Берлускони, H. Саркози). Общественно-резонансными они становятся, благодаря «присутствию» женщины, что свидетельствует о возврате к временам дворцового закулисья и фаворитизма, ситуация, в которой женщине отводилась роль «статиста» на фоне реальных внутриэлитных противоречий.

Другими словами, политизация приватной сферы становится механизмом запуска ограничения участия женщин в политической жизни. К такому выводу приходишь, если предположить, что концентрация внимания на приватных вопросах является эффективным способом ухода от сегрегации и дискриминации женщин, существовании и воспроизводстве неформальных ограничений политической карьеры и ухудшения положения женщины в контексте «патриархата» и попрания женских прав ради сохранения разнообразия традиций [2].

Общество политкорректности и мультикультурализма, основываясь на неформальных договоренностях, санкционирует домашнее насилие, если речь идет об этнокультурных меньшинствах, о приверженности принципу толерантности: критика либеральной концепции разделения политической и приватной сфер является инструментом обоснования приоритета до модернистской традиции над фундаментальными принципами модерна.

Популяризируемая в обществе мультикультурализма идея введения правового плюрализма, как содержащего возможность регулировать частное и семейное право, содержит тенденцию снятия женского вопроса в политике в том смысле, что женщина перестает быть политическим субъектом, a ее политические права отдаются на откуп традиции. Как писал польский социолог П. Штомпка, как и все, что создано человеком, традиции несут в себе функциональную амбивалентность [3]. Развивая эту мысль, можно сказать, что отказ от идей политического модерна, с целью убрать перегородки между приватной и общественной жизнью, выражается в парадоксальных последствиях, дискриминации женщины на основании правового плюрализма или «тихого» возврата к статистической роли путем релятивизации идей соучастия в политике.

Наконец, нельзя сказать, что политизация приватной сферы имеет только негативные моменты: обещающим для прогресса в решении женского вопроса является рост субполитик, передача ответственности в решении женской проблематики гражданским ассоциациям, как альтернативы ничейности политической системы, и попыткам вмешательства и прямого управления на основе политикоправовых норм и правил [4].

Эта тенденция чрезвычайно проблематична, но создает предпосылки для политической автономии женщины и укрепления потенциала участия включением новых политических акторов, обладающих способностью к экспертизе женских проблем, и контроля над деятельностью демократических институтов, которые могут продуцировать противоречивые, ограниченные решения женской проблематики на основе голосования.

Женщины не становятся центром политики, но их роль повышается в рамках требований консенсуса, использования формулы предварительных договоренностей и обязательного обсуждения вопросов «женской» политики. При этом меняется роль женских ассоциаций, которые эволюционируют от классической схемы представительства интересов к актуализации демократических ресурсов, способствующих снятию конфликтов между приватными, личными интересами женщины и ее правом быть личностью в политике. Внутри себя женские ассоциации вырабатывают формулу гражданской солидарности, сочетающей выбор в приватной сфере 
и равные шансы на осуществление политических прав в соответствии с демократическим самоуправлением общества и эгалитарным правопорядком [5].

\section{Литература}

1. Современная политическая теория. M., 2001. - C. 111.

Поступила в редакцฺию
2. Бенхабиб С. Притязания культуры. M., 2003. - C. 120.

3. Штомпка П. Социология социальных изменений. - М., 1996. - С. 96.

4. Бек У. Общество риска. На пути к другому модерну. - М., 2000. - C. 282.

5. Хабермас Ю. Политические работы. - M., 2005. - C. 279.

14 мая 2012 г.

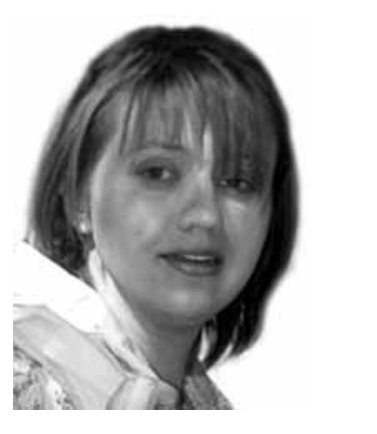

Оксана Алексеевна Дуброва - кандидат политических наук, доцент кафедры философии и педагогики Новочеркасской государственной мелиоративной академии.

Oksana Alekseyevna Dubrova - Ph.D., Candidate of Political Science, docent at the Philosophy and Pedagogics department of Novocherkassk State Land Reclamation Academy.

346400, г. Новочеркасск, ул. Пушкинская, 111, ауд. 213

111 Pushkinskaya st., r. 213, 346400, Novocherkassk, Rostov reg., Russia

Тел.: +7 (909) 435-81-96; e-mail: okdubrova@yandex.ru 